\title{
OBSERVATIONS ON THE HETEROGENEITY OF MALIC AND LACTIC DEHYDROGENASE IN HUMAN SERUM AND RED BLOOD CELLS ${ }^{1}$
}

\author{
By ELLIOT S. VESELL AND A. G. BEARN
}

(From the Rockefeller Institute for Medical Research, New York, N. Y.)

(Submitted for publication November 18, 1957; accepted January 30, 1958)

The enzyme malic dehydrogenase $(\mathrm{MDH})^{2}$ catalyzes the conversion of oxalacetic acid to malic acid. It resembles lactic dehydrogenase ( $\mathrm{LDH})$ in acting on an $\alpha$-keto acid substrate and in being a pyridine nucleotide dependent dehydrogenase:

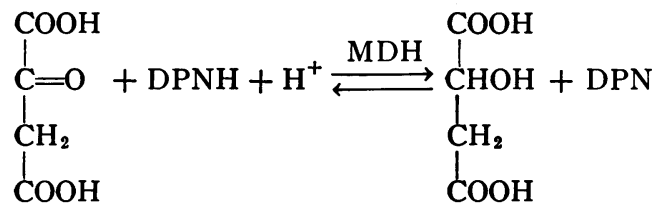<smiles>CC(=O)C(=O)[Pb]Nc1ccccc1</smiles>

It is of interest that Vallee has offered evidence that both rabbit muscle $\mathrm{LDH}$ and pig heart $\mathrm{MDH}$ are zinc enzymes $(1,2)$. Reports of elevated serum levels of $\mathrm{LDH}$ in cases of myocardial infarction and leukemia led to an earlier study (3) which demonstrated that normal human serum separated electrophoretically contained three enzymes with LDH activity and not one as had been anticipated. In an attempt to elucidate the nature of these three enzymes, an examination of the chemically analogous $\mathrm{MDH}$ system was undertaken. The results indicate that $\mathrm{MDH}$ activity is also found in three discrete electrophoretic fractions of the serum proteins, two of which closely resemble the corresponding $\mathrm{LDH}$ activity peaks.

\section{METHODS AND MATERIALS}

This study employed sera obtained from 14 subjects composed of 10 controls ( 2 healthy young men and 8 patients with such diseases as disseminated lupus erythe-

\footnotetext{
1 These studies were supported, in part, by a grant-inaid (A-1542) from the National Institute of Arthritis and Metabolic Diseases, National Institutes of Health.

2 The abbreviations used in this paper are as follows: $\mathrm{MDH}=$ malic dehydrogenase $; \mathrm{LDH}=$ lactic dehydrogenase ; $\mathrm{DPN}=$ diphosphopyridine nucleotide; $\mathrm{DPNH}=$ diphosphopyridine nucleotide reduced.
}

matosus, cirrhosis, Wilson's disease, and hepatitis), 2 cases of myocardial infarction and 2 cases of chronic lymphatic leukemia.

The method of zone electrophoresis, using a starch supporting medium in barbital buffer, $\mathrm{pH} 8.6$, with an ionic strength of 0.1 or 0.05 , was used to separate the serum proteins (4). After electrophoresis the starch block was cut into half inch segments, the protein eluted with $5.0 \mathrm{ml}$. buffer and its concentration determined by a modification of the Folin-Ciocalteau procedure (4). An aliquot of $2.5 \mathrm{ml}$. from each eluate was then assayed for MDH activity spectrophotometrically by the method of Wacker, Ulmer, and Vallee (5). Each eluate was incubated for 20 minutes at room temperature with 0.2 $\mathrm{ml}$. of 0.003 molar DPNH. The mixture was transferred to a Beckman cuvette of $1 \mathrm{~cm}$. path length; $0.1 \mathrm{ml}$. of 0.0076 molar oxalacetate was added, and the decrease in absorption at $340 \mathrm{~m} \mu$ was measured in the Beckman spectrophotometer. Readings were obtained every 30 seconds for 3 minutes. One unit of dehydrogenase activity was defined as a decrease in the optical density at $340 \mathrm{~m} \mu$ of 0.001 per minute. Under these conditions, the contribution to the observed $\mathrm{MDH}$ activity by the simultaneous measurement of $\mathrm{LDH}$, caused by spontaneous decarboxylation of oxalacetate to form pyruvate, was found to be negligible. Lactic dehydrogenase obtained from rabbit muscle (Worthington laboratories) was found to have insignificant quantities of activity when oxalacetate was used as substrate instead of pyruvate.

In several experiments, a $2.5 \mathrm{ml}$. sample of an hemolysate prepared from normal human red cells (6) was fractionated electrophoretically and an aliquot of the eluate was assayed for $\mathrm{MDH}$ activity. To determine the $\mathrm{pH}$ optima of the three peaks, $0.3 \mathrm{ml}$. was removed from the tube containing the maximum $\mathrm{MDH}$ activity, and added to tubes containing barbital buffers varying in $\mathrm{pH}$ from 7.4 to 9.2 , all at 0.1 ionic strength. $\mathrm{MDH}$ activity was then reassayed.

The effect of the inhibitors, ethylenediaminetetraacetic acid and $p$-chloromercuribenzoate, on each of the activity peaks was studied according to the method outlined below. Immediately after the serum fractions had been assayed for enzymatic activity the inhibitor was added, the solution thoroughly mixed and the activity redetermined. The decline in activity between the two measurements was attributed to the action of the inhibitor The final concentrations of ethylenediaminetetraacetic 


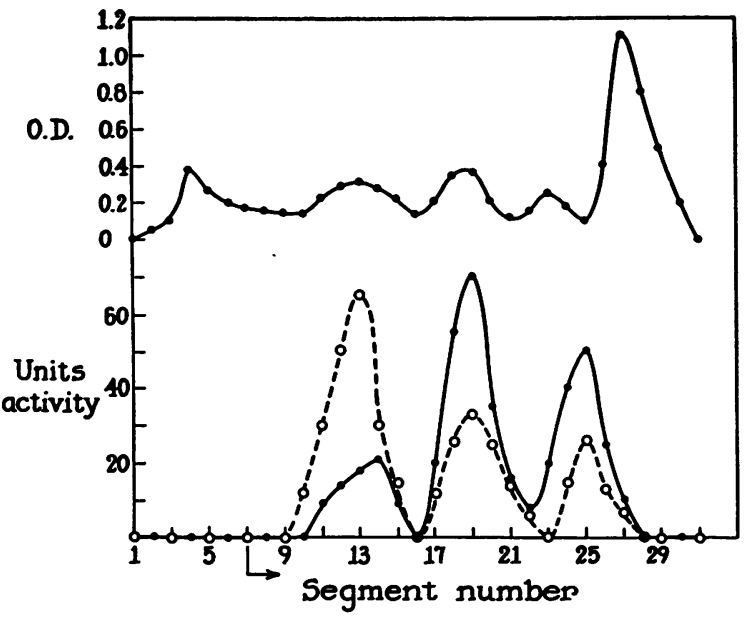

Fig. 1. Distribution of Malic and Lactic Dehydrogenase Activity in Normal Human Serum

Upper curve illustrates an electrophoric pattern of normal human serum. Lower curves illustrate distribution of malic and lactic dehydrogenase activity in serum fractions. The lactic dehydrogenase activity is indicated by the solid line and malic dehydrogenase activity by the broken line.

acid and p-chloromercuribenzoate were $6 \times 10^{-3} \mathrm{M}$ and $1 \times 10^{-4} \mathrm{M}$, respectively.

The experiments outlined above for serum $\mathrm{MDH}$ were also performed on serum LDH by substituting the substrate sodium pyruvate for sodium oxalacetate.

\section{RESULTS}

Each of the 14 sera separated electrophoretically and assayed for $\mathrm{MDH}$ and $\mathrm{LDH}$ activity revealed three main loci of activity (Figure 1 ). One was found in the $\beta$-globulin (peak 1 ); a second peak of activity was found in the $\alpha_{2}$-globulin (peak 2); and the third occurred between the $\alpha_{1}$-globulin and the albumin, hereafter referred to as the $\alpha_{1}$ peak (peak 3). Following electrophoresis, between 80 and 95 per cent of the $\mathrm{MDH}$ activity of the original serum was recovered from the starch block. An average of 9 per cent of the total activity remained adsorbed of the origin. However, the percentage varied widely and when fresh nonhemolyzed serum was used, the amount adsorbed at the origin was extremely small.

In the 10 control subjects (Table I), each peak of $\mathrm{MDH}$ activity contained a relatively constant percentage of the total activity found in serum. Forty-six per cent of the total MDH activity was found in the $\beta$-globulin, 26 per cent in the $\alpha_{2}$ -

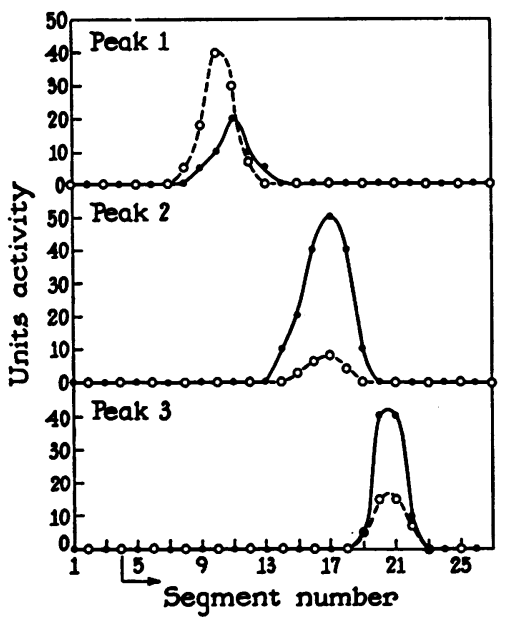

Fig. 2. The Pattern Obtained When Each Hemolysate Peak, After Having Been Isolated from a Starch Block, Was Rerun on a Second Block

The lactic dehydrogenase activity is indicated by the solid line and malic dehydrogenase activity by the broken line.

globulin, 19 per cent in the $\alpha_{1}$ peak and 9 per cent at the origin. The distribution of $\mathrm{LDH}$ activity among the three peaks differed from that of $\mathrm{MDH}$. The $\alpha_{2}$ peak contained the largest percentage of LDH activity; the $\beta$ peak had the largest percentage of MDH activity. Each of the three major components of $\mathrm{MDH}$ and $\mathrm{LDH}$ activity isolated was rerun under similar conditions and was found to have the same mobilities as in the starting material (Figure 2).

A comparison of the mobilities of the activity peaks of LDH and MDH revealed that the $\alpha_{1}$ peaks correspond closely as do the $\alpha_{2}$ peaks. However, the peak of LDH activity in the $\beta$-globulin was found to migrate slightly faster than the peak of MDH activity (Figures 1, 2, 3, and 4).

Experiments in which phosphate buffer of $\mathrm{pH}$ 7.5 and 0.1 ionic strength was used, instead of barbital buffer of $\mathrm{pH}$ 8.6, did not demonstrate any alteration in the correspondence of the $\alpha_{1}$ and $\alpha_{2}$ $\mathrm{MDH}$ and $\mathrm{LDH}$ activity peaks.

With sodium malate as substrate and DPN as coenzyme, it was found that the location of the three enzymes in the serum fractions was unchanged.

A parallel increase of the $\alpha_{1}$ peak of both $\mathrm{MDH}$ and LDH was observed in sera from two patients with acute myocardial infarction (Figure 3 ), 


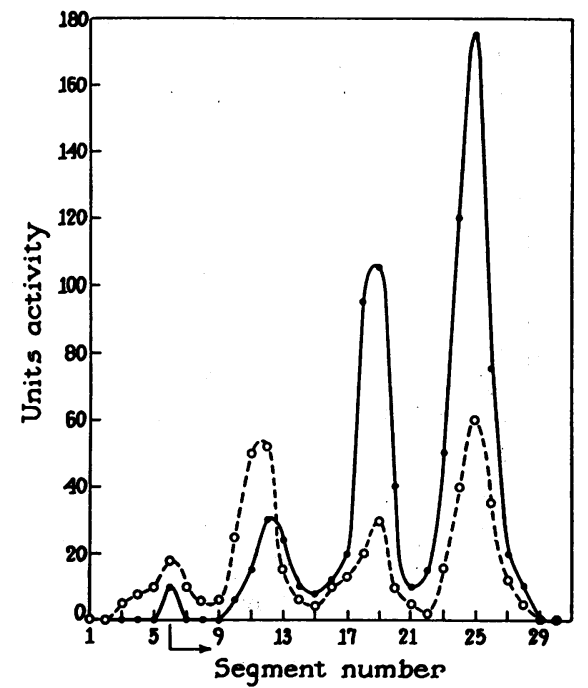

Fig. 3. Distribution of Malic and Lactic Dehydrogenase Activity in Serum from a Patient with Myocardial Infarction Illustrating Elevation of THE $\alpha_{1}$ PEAK

Note small activity adsorbed at the origin. The lactic dehydrogenase activity is indicated by the solid line and malic dehydrogenase activity by the broken line.

whereas an elevation of the $\alpha_{2}$ peak of both $\mathrm{MDH}$ and LDH was observed in sera from two cases of chronic lymphatic leukemia. Elevation of the $\alpha_{1}$

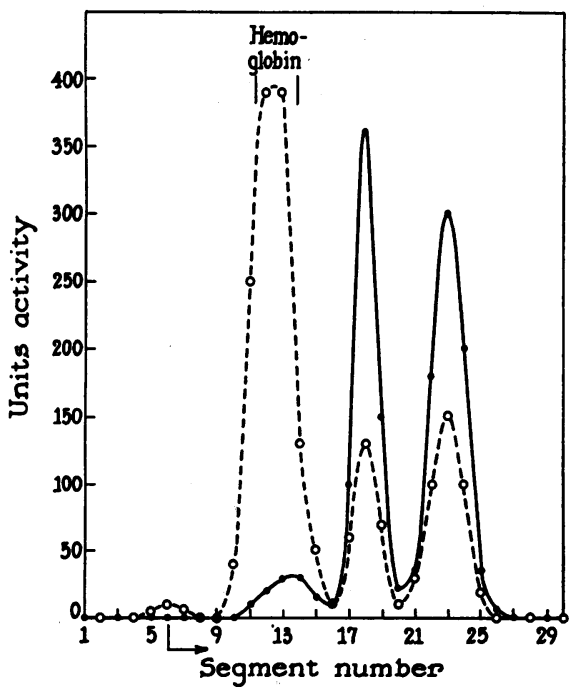

Fig. 4. Distribution of Malic and Lactic Dehydrogenase Activity in Hemolysate from Human Red Cells

Slight activity remains adsorbed at the origin. The lactic dehydrogenase activity is indicated by the solid line and malic dehydrogenase by the broken line. peak of LDH activity in cases of myocardial infarction and of the $\alpha_{2}$ peak of $\mathrm{LDH}$ activity in cases of leukemia has been reported previously (3).

Hemolysates obtained from human red cells, separated electrophoretically and analyzed for $\mathrm{MDH}$ and $\mathrm{LDH}$ revealed activity peaks similar in mobility to those found in serum (Figure 4). The activity peaks in the fractions of the hemolysate corresponding to the $\alpha_{2}$ and $\alpha_{1}$ peaks of serum occurred in regions where the protein concentration was extremely low. From the point of view of purification of these dehydrogenases, it is of interest that the ratio between the activity of the enzymes and the concentration of protein in the hemolysate fractions greatly exceeds the activity protein ratio in the serum fractions.

The results of the determinations of the $\mathrm{pH}$ optima in each of the three peaks of the red blood cell hemolysate are shown in Figure 5 . The $\mathrm{pH}$ optima for both MDH and LDH activity in the fraction of the hemolysate corresponding in mobility to the $\alpha_{2}$-globulin was 8.2. The MDH and LDH activity in the hemolysate fraction corresponding in mobility to the $\alpha_{1}$-globulin was found to be maximal at 8.5 , but in the hemolysate fraction, corresponding in mobility to the $\beta$-globulin, the optimum $\mathrm{pH}$ for $\mathrm{MDH}$ differed from that for $\mathrm{LDH}$. A pH of 8.9 was required for maximum $\mathrm{MDH}$ activity, whereas the optimum $\mathrm{pH}$ for $\mathrm{LDH}$ activity was 8.0.

Experiments with ethlyenediaminetetraacetic acid and $p$-chloromercuribenzoate showed that under the conditions employed, approximately 50 per cent inhibition occurred in each of the three activity peaks for both $\mathrm{MDH}$ and $\mathrm{LDH}$.

\section{DISCUSSION}

Two of the three dehydrogenases in serum and red blood cells which reduce oxalacetate are indistinguishable in electrophoretic mobility and in $\mathrm{pH}$ optima from those which reduce pyruvate. A further indication of the similarity of the enzyme producing these two activity peaks is that the elevation of the $\alpha_{1}$ peak found in serum from patients with myocardial infarction occurs with either pyruvate or oxalacetate as substrates. Similarly, elevation of the $\alpha_{2}$ peak found in serum from patients with leukemia is present with either 
substrate. Alterations in the electrophoretic conditions have failed thus far to separate the dehydrogenase activities obtained in the $\alpha_{1}$ and $\alpha_{2}$ peaks. In contrast, the activities in the $\beta$-globulin peak are clearly separable and thus more than one enzyme must be present.

In this connection it is pertinent that Meister has shown that many different $\alpha$-keto and $\alpha$-diketo acids, including oxalacetic acid, can serve as substrates for $\mathrm{LDH}$ obtained from rabbit muscle (7). In addition, Davies and Kun have described several $\alpha$-hydroxy dicarboxylic acids which act as substrates for $\mathrm{MDH}$ obtained from pig heart (8). Recently, alcohol dehydrogenase from yeast has been shown to oxidize lactate and reduce pyruvate (9).

The finding of three dehydrogenases in serum which reduce pyruvate and of three which reduce oxalacetate is in harmony with recent evidence for the heterogeneity of enzymes previously thought to be homogeneous, and suggests that the elevated levels of total serum $\mathrm{LDH}$ and $\mathrm{MDH}$ found in many disease states $(5,10-12)$ should be evaluated in the light of this heterogeneity. The restriction of elevated levels of $\mathrm{MDH}$ and LDH activity to the $\alpha_{2}$ peak in cases of leukemia and to the $\alpha_{1}$ peak in cases of myocardial infarction, suggests that considerably more information may be obtained concerning dehydrogenase activity in disease states when fractionation is performed than when the measurement of activity is confined to whole serum.

Additional evidence for the heterogeneity of $\mathrm{LDH}$ is provided by Neilands, who demonstrated that crystalline $\mathrm{LDH}$ prepared from beef heart muscle, although monodisperse in the ultracentrifuge, exhibits two peaks of activity following

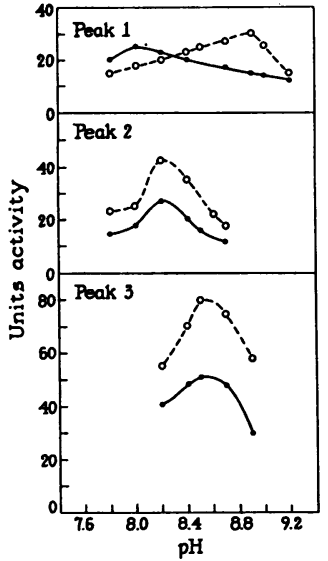

Fig. 5. Curves Showing pH Optima for the Three Peaks of Activity Obtained from Red Cell HemolySATE

The lactic dehydrogenase activity is indicated by the solid line and malic dehydrogenase by the broken line.

electrophoresis $(7,13)$. Wieland and Pfleiderer have also observed the existence of more than one enzyme with LDH activity (14) in several organs of the rat. Different forms of pepsin (15), chymotrypsin (16), cytochrome c (17), ribonuclease (18), lysozyme (19), and enolase (20) also have been described.

Ultracentrifugation studies have failed thus far to demonstrate conclusively whether or not the $\mathrm{LDH}$ activity in serum is attributable to more than one component (21). Indeed the possibility that a single protein with polymeric forms, as in the case of muscle phosphorlylase (22), might yield three electrophoretic peaks of activity cannot be entirely ruled out. Moreover, the experimental evidence presented in this paper does not eliminate the possibility of the existence of two

TABLE I

Malic dehydrogenase activity in serum fractions

\begin{tabular}{|c|c|c|c|c|c|c|c|}
\hline & \multirow{2}{*}{$\begin{array}{l}\text { No. of } \\
\text { cases }\end{array}$} & \multirow{2}{*}{$\begin{array}{c}\text { Total } \\
\text { activity }\end{array}$} & \multicolumn{3}{|c|}{ Per cent total activity } & \multirow[b]{2}{*}{ Origin } & \multirow[b]{2}{*}{$\alpha_{2} / \alpha_{1}$} \\
\hline & & & $\beta$ & $\alpha_{2}$ & $\alpha_{1}$ & & \\
\hline Controls & 10 & $\begin{array}{c}316 \\
(224-450)\end{array}$ & $\begin{array}{c}46 \\
(40-54)\end{array}$ & $\begin{array}{c}26 \\
(18-30)\end{array}$ & $\begin{array}{c}19 \\
(14-25)\end{array}$ & $\begin{array}{c}9 \\
(0-18)\end{array}$ & $\begin{array}{c}1.4 \\
(1.0-1.7)\end{array}$ \\
\hline Myocardial infarction & 2 & $\begin{array}{l}604 \\
473\end{array}$ & $\begin{array}{l}32 \\
28\end{array}$ & $\begin{array}{l}19 \\
20\end{array}$ & $\begin{array}{l}47 \\
41\end{array}$ & $\begin{array}{l}12 \\
11\end{array}$ & $\begin{array}{l}0.4 \\
0.4\end{array}$ \\
\hline Leukemia & 2 & $\begin{array}{l}233 \\
261\end{array}$ & $\begin{array}{l}38 \\
37\end{array}$ & $\begin{array}{l}49 \\
43\end{array}$ & $\begin{array}{l}13 \\
20\end{array}$ & $\begin{array}{l}0 \\
0\end{array}$ & $\begin{array}{l}3.7 \\
2.1\end{array}$ \\
\hline
\end{tabular}


chemically distinguishable enzymes (MDH and $\mathrm{LDH})$ in the $\alpha_{2}$ peaks and of two different dehydrogenases in the $\alpha_{1}$ peaks. However, since zone electrophoresis and $\mathrm{pH}$ optima have failed to reveal differentiating characteristics, the possibility that $\mathrm{MDH}$ and $\mathrm{LDH}$ activity in the $\alpha_{2}$ peaks may be attributable to one enzyme, and that one enzyme may be responsible for $\mathrm{MDH}$ and LDH activity in the $\alpha_{1}$ peaks, should not be summarily dismissed.

The suggestion (23) that the three peaks of xanthine dehydrogenase activity, which have been demonstrated electrophoretically in rat serum, are attributable to binding by lipoproteins does not apply to LDH. High speed centrifugation in a density gradient did not reveal significant activity in those fractions rich in lipoproteins.

Purified preparations of $\mathrm{MDH}$ and $\mathrm{LDH}$ isolated from tissues have been shown to possess distinguishable physical properties and substrate specificities $(7,24)$. However, these observations are not discordant with the results of this study, since enzymes performing similar functions in different tissues do not always have the same substrate specificities (25).

\section{SUM M ARY}

1. Human serum separated electrophoretically was found to exhibit three regions of $\mathrm{MDH}$ activity. In 10 control subjects the percentage of $\mathrm{MDH}$ activity in each peak remained relatively constant, although the total activity in serum varied widely. Hemolysates from red cells separated electrophoretically revealed three peaks of dehydrogenase activity similar to those found in serum.

2. The MDH activity peaks in the $\alpha_{2}$-globulin and between the $\alpha_{1}$-globulin and albumin corresponded in mobility and in $\mathrm{pH}$ optima to the $\mathrm{LDH}$ activity found in the same regions. Alteration in the electrophoretic conditions thus far employed have failed to separate the proteins acting on these substrates in the two activity peaks. However, the $\mathrm{LDH}$ activity peak in the $\beta$-globulin differed from the $\mathrm{MDH}$ activity peak, both in electrophoretic mobility and $\mathrm{pH}$ optima.

3. The similarities between the $\alpha_{2}$ activity peaks of $\mathrm{MDH}$ and $\mathrm{LDH}$ raise the question of whether the $\alpha_{2}$ peaks may be due to a single protein which can act on either substrate. Similarly, the possibility that the $\alpha_{1}$ peaks of $\mathrm{MDH}$ and LDH activity may also be produced by one enzyme is discussed. Further studies will be required to settle these questions.

4. It is suggested that the multiplicity of the dehydrogenase enzymes in serum should be considered in evaluating observations of total enzymatic activity in disease states.

\section{- REFERENCES}

1. Vallee, B. L., and Wacker, W. E. C. Zinc, a component of rabbit muscle lactic dehydrogenase. J. Amer. chem. Soc. 1956, 78, 1771.

2. Vallee, B. L., Hoch, F. L., Adelstein, S. J., and Wacker, W. E. C. Pyridine nucleotide dependent metallodehydrogenases. J. Amer. chem. Soc. 1956, 78, 5879.

3. Vesell, E. S., and Bearn, A. G. Localization of lactic acid dehydrogenase activity in serum fractions. Proc. Soc. exp. Biol. (N. Y.) 1957, 94, 96.

4. Kunkel, H. G. Zone electrophoresis in Meth. biochem. Anal., David Glick, Ed. New York, Interscience Publishers, Inc. 1954, vol. 1, p. 141.

5. Wacker, W. E. C., Ulmer, D. D., and Vallee, B. L. Metalloenzymes and myocardial infarction. II. Malic and lactic dehydrogenase activities and zinc concentrations in serum. New Engl. J. Med. 1956, 255, 449.

6. Drabkin, D. L. Spectrophotometric studies. XIV. The crystallographic and optical properties of the hemoglobin of man in comparison with those of other species. J. biol. Chem. 1946, 164, 703.

7. Meister, A. Reduction of $\alpha_{1}-\gamma$-diketo and $\alpha$-keto acids catalyzed by muscle preparations and by crystalline lactic dehydrogenase. J. biol. Chem. 1950, 184, 117.

8. Davies, D. D., and Kun, E. Isolation and properties of malic dehydrogenase from ox-heart mitochondria. Biochem. J. 1957, 66, 307.

9. van Eys, J., and Kaplan, N. O. Yeast alcohol dehydrogenase. III. Relation of alcohol structure to activity. J. Amer. chem. Soc. 1957, 79, 2782.

10. Wróblewski, F., and La Due, J. S. Lactic dehydrogenase activity in blood. Proc. Soc. exp. Biol. (N. Y.) 1955, 90, 210.

11. Hill, B. R. Some properties of serum lactic dehydrogenase. Cancer Res. 1956, 16, 460.

12. White, L. P. Serum enzymes. I. Serum lactic dehydrogenase in myocardial infarction. New Engl. J. Med. 1956, 255, 984.

13. Neilands, J. B. The purity of crystalline lactic dehydrogenase. Science 1952, 115, 143.

14. Wieland, T., and Pfleiderer, G. Nachweis der Heterogenität von Milchsäure-dehydrogenasen verschiedenen Ursprungs durch Trägerelektrophorese. Biochem. Z. 1957, 329, 112. 
15. Desreux, V., and Herriott, R. M. Existence of several active components in crude pepsin preparations. Nature (Lond.) 1939, 144, 287.

16. Kunitz, M. Formation of new crystalline enzymes from chymotrypsin. Isolation of Beta and Gamma chymotrypsin. J. gen. Physiol. 1938, 22, 207.

17. Paléus, S., and Neilands, J. B. Preparation of cytochrome $c$ with the aid of ion exchange resins. Acta chem. scand. 1950, 4, 1024.

18. Hirs, C. H. W., Stein, W. H., and Moore, S. Chromatography of proteins. Ribonuclease. J. Amer. chem. Soc. 1951, 73, 1893.

19. Tallan, H. H., and Stein, W. H. Studies on lysozyme. J. Amer. chem. Soc. 1951, 73, 2976.

20. Malmström, B. G. The purification of yeast enolase by zone electrophoresis and ion-exchange chromatography, and the existence of several active forms of the enzyme. Arch. Biochem. 1957, 70, 58.
21. Hill, B. R., Kuff, E. L., and Hogeboom, G. H. Sedimentation behavior of serum lactic dehydrogenase. Proc. Soc. exp. Biol. (N. Y.) 1956, 92, 430.

22. Madsen, N. B., and Gurd, F. R. N. The interaction of muscle phosphorylase with $p$-chloromercuribenzoate. III. The reversible dissociation of phosphorylase. J. biol. Chem. 1956, 223, 1075.

23. Mitidieri, E., Ribeiro, L. P., Affonso, O. R., and Villela, G. G. Localization of zanthine dehydrogenase in rat serum by paper electrophoresis. Biochim. biophys. Acta 1955, 17, 587.

24. Wolfe, R. G., and Neilands, J. B. Some molecular and kinetic properties of heart malic dehydrogenase. J. biol. Chem. 1956, 221, 61.

25. Whittaker, V. P. Specificity, mode of action and distribution of cholinesterases. Physiol. Rev. 1951, 31, 312. 